\title{
Direct fluorescent antibody test and bacteriological culture for detection of Brucella suis in swine tissues
}

\author{
Estein, S.M. ${ }^{1,6}$; Bence, A.R. ${ }^{2,5}$; Cacciato, C.S. ${ }^{3,5}$; Echavarría, H.M.; Soto, P.,4 \\ ${ }^{1}$ Lab.Inmunología CIVETAN-CONICET, ${ }^{2}$ Dep.Fisiopatología, ${ }^{3}$ Lab.Microbiología, Fac.Cs.Vet.UNCPBA, \\ Tandil, Buenos Aires, Argentina. ${ }^{4}$ Lab.Tandil. ${ }^{5}$ Comisión Investig.Científ. (CICPBA). \\ ${ }^{6}$ Consejo Nac.Investig.Científ.Técn. (CONICET). \\ E-mail: silmares@vet.unicen.edu.ar
}

\begin{abstract}
Estein, S.M.; Bence, A.R.; Cacciato, C.S.; Echavarría, H.M.; Soto, P.: Direct fluorescent antibody test and bacteriological culture for detection of Brucella suis in swine tissues. Rev. Vet. 30: 1, 39-42, 2019. Methods available for detection of Brucella sp from different specimens include bacteriological culture or detection of specific DNA fragments by polymerase chain reaction. The use of fluorescein-labeled anti-Brucella globulin for demonstrating this antigen in animal tissues is a simple, easy, reproducible, cheap and fast technique. The aim of this work was to evaluate the gamma globulin fraction of polyclonal anti-Brucella abortus serum labeled with fluorescein iso-tio-cyanate (FITC-labeled antibody): 1) against different smooth and rough Brucella sp, 2) against bacterium of other genus, and 3) to compare direct fluorescent antibody test results with bacteriological culture for the detection of $B$. suis in different tissues from infected animals. This conjugate stained all Brucella $s p$ with different intensities but it did not stain any heterologous bacterium tested. Background fluorescence associated with its use on smears from infected sources of different specimens was particularly low. Most of the infected tissues showed the presence of yellowish-green fluorescent organisms with brucella morphology. The tested FITC-labeled antibody allows a quick, effective and inexpensive diagnosis of brucellosis.
\end{abstract}

Key words: swine, Brucella sp, fluorescein-labeled anti-Brucella globulin, smear, sensitivity, specificity.

\begin{abstract}
Resumen
Estein, S.M.; Bence, A.R.; Cacciato, C.S.; Echavarría, H.M.; Soto, P.: Comparación del test directo de anticuerpos fluorescentes y el cultivo bacteriológico para detección de Brucella suis. Rev. Vet. 30: 1, 39-42, 2019. El diagnóstico de brucelosis se apoya en el cultivo bacteriológico o en la detección de fragmentos de $\mathrm{ADN}$ de la bacteria mediante la reacción en cadena de la polimerasa. El empleo de una inmunoglobulina anti-Brucella conjugada a fluoresceína para la detección de este antígeno en tejidos constituye una técnica simple, fácil, reproducible, económica y rápida. El objetivo de este trabajo fue evaluar la fracción gammaglobulínica de un suero policlonal anti-Brucella abortus marcada con isotiocianato de fluoresceína (FITC), 1) contra distintas especies lisas y rugosas de Brucella $s p$, 2) contra bacterias de otros géneros, y 3) comparar los resultados obtenidos con la inmunofluorescencia directa y el cultivo bacteriológico para la detección de $B$. suis en distintos tejidos de porcinos infectados. Este conjugado detectó todas las brucelas con distinta intensidad de fluorescencia, pero no hubo fluorescencia inespecífica cuando se ensayaron las bacterias de otros géneros. La fluorescencia de fondo en muestras de los distintos tejidos infectados fue baja. La mayoría de los tejidos infectados mostraron la presencia de microorganismos verde-fluorescentes con la morfología de las brucelas. El anticuerpo conjugado a FITC permitió un diagnóstico de brucelosis rápido, efectivo y económico.
\end{abstract}

Palabras clave: cerdo, Brucella sp, fluoresceína anti-Brucella globulina, impronta, sensibilidad, especificidad.

\section{INTRODUCTION}

Brucellosis is caused by gram-negative Brucella $s p$ and is one of the most widespread zoonoses and an economically important disease ${ }^{1}$. Direct diagno- ses include isolation of these bacteria by culture and identification by biochemical tests, or detection of DNA sequences by polymerase chain reaction (PCR).

Cultural examination takes a long time and is not always suitable even on selective media, because of 
overgrowth by contaminating organisms ${ }^{3}$. PCR is an extremely powerful technique but requires DNA extraction from samples and the use of specific equipment.

The direct fluorescent antibody test (DFAT) appears to offer a specific and quick alternative to the Gram or stamp stains onto smears from tissues or suspicious colonies ${ }^{2}$. DFAT is a common laboratory technique, which is based on the use of specific antibodies chemically conjugated to fluorescent dyes. The fluorescence can be visualized by a fluorescence microscope used for the routine diagnosis(e.g. diagnosis of campylobacteriosis) ${ }^{7}$.

The aim of this work was evaluate the gammaglobulin fraction of polyclonal anti-Brucella abortus serum labeled with fluorescein iso-tio-cyanate (FITC-labeled antibody): 1) against different smooth and rough $\mathrm{Bru}$ cella sp; 2) against bacterium of other genus; and 3) to compare DFAT results with bacteriological culture for the detection of B. suis in different tissues from seropositive pigs.

\section{MATERIAL AND METHODS}

Serological tests. Serum samples from aborted sow and boar were analyzed by Buffer Plate Agglutination test (BPAT), Bengal Rose Test (RBT) and Fluorescense Polarization Assay (FPA) following supplier instructions (Laboratorio Biológico de Tandil, Argentina). Results were interpreted according to the procedures recommended by Servicio Nacional de Sanidad y Calidad Agroalimentaria (SENASA) ${ }^{8}$.

Tissue samples, bacteriological culture. Material from fetal tissues, aborted sow and boar from brucellosis endemic farm were submitted for routine diagnosis and were used in this study. Samples were taken of 4 liver and spleen fetal tissues; placenta, spleen and liver from an aborted sow; and spleen, liver, testes, seminal glands, prostate and bulbouretral glands, epididymis (head, body and tails), right and left testes and cervical and inguinal lymph nodes from a boar. Each sample was homogenized in saline solution and was seeded onto skidrow and tryptone soy agar added with yeast (TSAYE) media. Plates were incubated in $10 \%$ of $\mathrm{CO}_{2}$ at $37^{\circ} \mathrm{C}$ for ten days. Suspected colonies were identified by Gram staining, catalase, oxidase, urease, nitrate reductase tests and $\mathrm{SH}_{2}$ production ${ }^{4}$.

Smears. Impression smears from all tissue samples were made onto glass slides and allowed to air-dry. Procedure to staining was detailed in "determination of conjugate specificity" using the optimal dilution of the fluorescein conjugate determined by check board titration against different smooth Brucella sp (1:200). Only the presence of individual or clumping yellowishgreen fluorescent organisms with the morphological characteristics of Brucella $s p$ was considered positive. Control smears of smooth $B$. abortus suspensions were included in each series of tests. A suspension of $B$. abortus strain was included, as positive control of the reaction.
Polyclonal anti-Brucella abortus serum. Polyclonal anti-B. abortus serum was produced by laboratorio biológico de Tandil (Biotandil SRL). Briefly, specific antibodies against $B$. abortus were purified from the serum of hyperimmunized goat. Goat was immunized with inactivated $B$. abortus S19 suspension four times by intramuscular via. The gamma globulin fraction from the serum was precipitated by the addition of ammonium sulphate. This fraction was conjugated to FITC as previously described by other investigators ${ }^{9}$.

Determination of conjugate specificity. To determine the specificity of the fluorescent conjugate, it was diluted in Phosphate Buffered Saline (PBS) $\mathrm{pH} 8$ at the following 10 dilutions: $1 / 25,1 / 50,1 / 100,1 / 150$, $1 / 200,1 / 300,1 / 400,1 / 500$ and 1/600. Ten microliters of each bacterial suspension was smeared in each one of 12 wells printed with ink per glass slide and was airdried at $37^{\circ} \mathrm{C}$. Smears were fixed with absolute ethanol at $37^{\circ} \mathrm{C}$ and then rinsed with distilled water. Twenty microliters of each conjugate dilution were added to each reaction site on the slides. Reaction was allowed to proceed in a moist atmosphere at $37^{\circ} \mathrm{C}$ for 1 hour. Conjugate was rinsed off with PBS three times and then with distilled water once. Cover slips were mounted with buffered glycerol $(\mathrm{pH} 8)$ and were examined by fluorescence microscopy with incident lamination

Table 1. Bacteriological culture and DFAT in different tissues from fetal swine tissues, aborted sow and boar with positive serology.

\begin{tabular}{|c|c|c|c|}
\hline origin & tissues & DFAT & bact.culture \\
\hline \multirow{8}{*}{ fetal } & liver of F1 & positive & positive \\
\hline & spleen of F1 & positive & positive \\
\hline & liver of F2 & positive & positive \\
\hline & spleen of F2 & positive & positive \\
\hline & liver of F3 & positive & positive \\
\hline & spleen of F3 & positive & positive \\
\hline & liver of F4 & positive & positive \\
\hline & spleen of F4 & positive & positive \\
\hline \multirow{5}{*}{ female } & placenta & positive & positive \\
\hline & cervical lymph. & negative & negative \\
\hline & inguinal lymph. & negative & positive \\
\hline & spleen & positive & positive \\
\hline & liver & negative & negative \\
\hline \multirow{12}{*}{ male } & right teste & positive & positive \\
\hline & left teste & negative & negative \\
\hline & spleen & negative & positive \\
\hline & liver & negative & positive \\
\hline & seminal glands & negative & negative \\
\hline & prostate gland & positive & positive \\
\hline & left head of ep. & negative & negative \\
\hline & right head of ep. & positive & positive \\
\hline & leftbody of ep. & negative & negative \\
\hline & rightbody of ep. & positive & positive \\
\hline & lefttail of ep. & negative & negative \\
\hline & righttail of ep. & positive & positive \\
\hline
\end{tabular}

DFAT: direct fluorescent antibody test; bact.: bacteriological; ep: epididymis; F1 to F4: fetal organs. 
Table 2. Fluorescence intensities against different bacterium after incubation with fluorescein-labeled antiBrucella globulin.

\begin{tabular}{|c|c|c|c|c|c|c|c|c|c|c|}
\hline \multirow{2}{*}{ bacteria } & \multicolumn{10}{|c|}{ anti-Brucella fluorescent conjugate dilutions } \\
\hline & $1 / 25$ & $1 / 50$ & $1 / 75$ & $1 / 100$ & $1 / 150$ & $1 / 200$ & $1 / 300$ & $1 / 400$ & $1 / 500$ & $1 / 600$ \\
\hline Brucilla abortus 544 (S) & +++ & +++ & +++ & +++ & +++ & +++ & +++ & +++ & +++ & +++ \\
\hline B. melitensis $\mathrm{H} 38(\mathrm{~S})$ & +++ & ++1 & ++1 & ++1 & ++1 & ++1 & ++ & +1 & +1 & +1 \\
\hline B. suis $1330(\mathrm{~S})$ & +++ & +++ & +++ & +++ & +++ & +++ & +++ & +++ & +++ & +++ \\
\hline B. canis RM6/66 (R) & ++1 & ++1 & ++1 & ++1 & +1 & +1 & + & + & + & + \\
\hline B. canis $\mathrm{M}-(\mathrm{R})$ & +1 & +1 & + & + & 1 & - & - & - & - & - \\
\hline B. ovis REO 198(R) & +1 & +1 & + & I & - & - & - & - & - & - \\
\hline Actinobacillus seminis & - & - & - & - & - & - & - & - & - & - \\
\hline Campylobacter fetus & 1 & - & - & - & - & - & - & - & - & - \\
\hline Escherichia coli & - & - & - & - & - & - & - & - & - & - \\
\hline Histophilus somni & - & - & - & - & - & - & - & - & - & - \\
\hline Mannheimia haemolytica & - & - & - & - & - & - & - & - & - & - \\
\hline Proteus vulgaris & - & - & - & - & - & - & - & - & - & - \\
\hline Corynebacterium pseudoTBC & 1 & 1 & 1 & I & - & - & - & - & - & - \\
\hline Staphylococcus aureus & - & - & - & - & - & - & - & - & - & - \\
\hline Trueperella pyogenes & II & 1 & - & - & - & - & - & - & - & - \\
\hline
\end{tabular}

Fluorescence intensity of conjugate: $(+++)$ extremely positive reaction, $(++I)$ strongly positive reaction, $(++)$ mild reaction, $(+)$ moderate reaction, $(+I)$ weakly positive reaction, (I) weak reaction, $(-)$ negative reaction.

at 100x (Zeiss-Primo Star). The highest conjugate dilution at which fluorescence was detected in each bacterial smear was taken as a final end point.

Bacteria. To check cross-reactivity of the fluorescent conjugate, individual suspensions of different smooth (Brucella abortus 544, B. melitensis H38, B. suis 1330) and rough Brucella strains (B. canis RM6/66, B. canis (M-), B. ovis REO 198), other Gram negatives (Actinobacillus seminis, Campylobacter fetus, Escherichia coli, Histophilus somni, Mannheimia haemolytica, Proteus vulgaris) and Gram positives (Corynebacterium pseudotuberculosis, Staphylococcus aureus, Trueperella pyogenes (ex-Arcanobacterium) bacteria were inactivated and were prepared in phenol saline solution. After that, density of each bacterial suspension was adjusted to match turbidity standard of $0.5 \mathrm{McFar}-$ land units (approximately $1.5 \times 10^{8}$ bacteria).

Statistical analysis. The kappa index of concordance between bacteriological culture and DFAT was determined by EPIDAT 4.2

\section{RESULTS}

Serum samples from aborted sow and boar were positive in the three techniques used to evaluate the presence of anti-Brucella antibodies. Tissue samples were seeded in a base and selective media. Bacteriological results and DFAT assayed onto tissue smears are shown in Table 1.

The results obtained after incubation of FITC-labeled anti- $B$. abortus conjugate with different bacterial suspensions are shown in Table 2. Extremely positive and strongly positive reactions were observed in high dilutions of conjugate against all tested smooth $B$. abortus, $B$. suisand, and $B$. melitensis reference strains (Figure 1: A, B, and C).
However, fluorescent conjugate reacted with strong to weak intensity and in low dilutions against $B$. $c a$ nis or $B$. ovis reference strains. No fluorescent bacteria were seen in preparations from other Gram positive or Gram negative bacteria that can cause serological cross reaction with Brucella sp in different domestic animals.

Substantial concordance was observed between bacteriological culture (gold standard) and DFAT (kappa=0.6923; (IC 95\% 0.47-1)). Tissue smears from pigs infected with Brucella $s p$ showed the presence of yellowish-green fluorescent organisms of brucella morphology located in clumps or individual particles (Figure 1: D and E). Occasionally, in all types of preparation, isolated particles showing yellowish fluorescence or indistinct patches showing similar fluorescence were observed.

\section{DISCUSSION}

Although a presumptive diagnosis of brucellosis can be made by demonstrating high or rising antibody titers to Brucella antigens, isolation of the organism from fluids or tissue cultures is the only irrefutable proof of the disease ${ }^{4}$.

On the basis of the actual work we confirm that DFAT with this FITC-labeled anti-B.abortus conjugate allows safe and quick detection of Brucella $s p$ onto smears of specimen or tissue from suspicious animals or from isolated colonies of brucella.

In addition, the direct binding of the polyclonal antibody to specific epitopes reduces the number of steps in the procedure, saving time and reducing non-specific background signal ${ }^{6}$. This also limits the possibility of antibody cross-reactivity and possible mistakes throughout the process. 

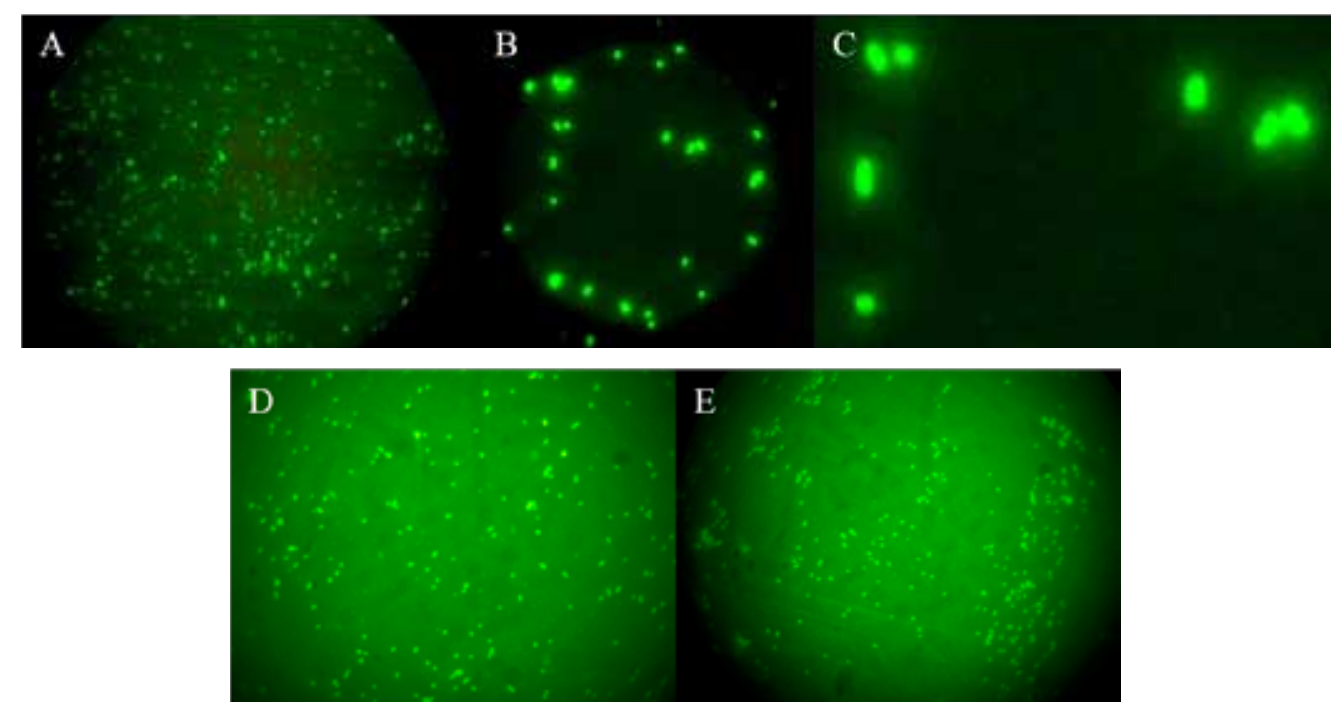

Figure 1. Direct fluorescence antibody test with polyclonal FITC conjugated anti-B. abortus serum. A, B, C: suspension of Brucella suis 1330. D: swine epididymal smear infected with B. suis biovar 1. E: smear from prostate gland (100x immersion oil).

Since already it has been demonstrated by other authors, the use of this technique as a first step for diagnostic would allow much quicker results than bacteriological culture whose time is extensive and where isolation is subject to viability of the bacterium and to the employment of selective culture media that prevent the growth of contaminants ${ }^{5}$.

Acknowledgements. We thank Drs. N.Guida (UBA) and F.Paolicchi (INTA Balcarce) for the strains provided, and J.Garcia, B.Riccio, G.Yaniz, P.Dominguez and M. Indart by the technical help in the necropsies.

\section{REFERENCES}

1. Adone R, Pasquali P. 2013. Epidemiosurveillance of brucellosis. Rev Sci Tech 32: 199-205.

2. Ajai CO, Cook JE, Dennis SM. 1980. Diagnosing ovine epididymitis by immunofluorescence. Vet Rec 107: 421424.

3. Al Dahouk S, Tomaso H, Nöckler K, Neubauer H, Frangoulidis D. 2003. Laboratory-based diagnosis of brucellosis-a review of the literature. Part I: Techniques for direct detection and identification of Brucella sp Clin Lab 49: 487-505.
4. Alton GG, Jones LM, Angus RD, Verger JM. 1988. Serological methods. Techniques for the Brucellosis laboratory. Ed. Institut National de la Recherche Agronomique, Paris, p. 157-167.

5. Corbel MJ. 1973. The direct fluorescent antibody test for detection of Brucella abortus in bovine abortion material. J Hyg 71:123-129.

6. Fritschy J, Härtig W. 2001. Immunofluorescence. doi:10.1038/npg.els.0001174. https://onlinelibrary.wiley. com/doi/10.1038/npg.els.0001174

7. Mellick PW, Winter AJ, McEntee K. 1965. Diagnosis of vibriosis in the bull by the use of the fluorescent antibody technique. Corn Vet 55: 280-294.

8. Nicola A, Elena S. 2009. Manual de diagnóstico serológico de la brucelosis bovina, Ed. SENASA, Buenos Aires, p. 95.

9. Soto P, Di Rocco MJ. 1984. Campylobacteriosis bovina. Prevalencia en diversas zonas de la República Argentina. Rev Investig Agropec 19: 273-279. 